\title{
Germination and interspecific grafting of passion fruit
}

\author{
Roseano Medeiros da Silva ${ }^{*}$, Ana Verônica Menezes de Aguiar' ${ }^{1}$ Kaio Gráculo Vieira Garcia², \\ Fábio Gelape Faleiro ${ }^{3}$, Vander Mendonça' ${ }^{1}$ Eudes de Almeida Cardoso'
}

\author{
'Federal University of the Semi-Arid, Mossoró, Brazil \\ ${ }^{2}$ Federal University of Ceará, Fortaleza, Brazil \\ ${ }^{3}$ Brazilian Agricultural Research Corporation, Planaltina, Brazil \\ *Corresponding author, e-mail: roseanomedeiros@gmail.com
}

\begin{abstract}
The objective of this study is to evaluate the seed germination and efficiency of grafting yellow passion fruit on six Passifloraceae species. The species used as rootstocks were Passiflora foetida L., P. cincinnata Mast., P. ligularis Juss., P. caerulea L., P. gibertii N. E. Brown, and P. edulis Sims. The study involved six treatments with four replicates of eight plants per plot and was arranged in a completely randomized block design. The seedlings were produced on a non-sterile substrate composed of a mixture of soil and bovine manure at the ratio of 3:1. The percentage of germination was high for all studied species, and the rate of graft development and survival was higher than 70 and $85.71 \%$, respectively, within 60 days after grafting.
\end{abstract}

Keywords: Passiflora edulis Sims., species, propagation

\footnotetext{
Passionflower belongs to the Passifloracea family and grows in tropical climates. Brazil is the world's largest producer and consumer of passion fruit (Passiflora edulis Sims.), with a total average production of 823,000 tons and yield of approximately $14.3 \mathrm{tha}^{-1}$ in 2014 (ABF, 2016). According to the same source, passion fruit was the fourth fruit most produced (381 t) in the state of Bahia, representing approximately $46 \%$ of the national production.

Although Brazil is the largest producer, the production does not meet the domestic demand. Moreover, the occurrence of phytosanitary problems has decreased the service life and yield of the crops.
} On a commercial scale, passion fruif is usually propagated by sexual reproduction. However, this type of reproduction causes serious problems in field conditions because of the susceptibility of the crop to diseases caused by soil fungi, and fungal infections are the leading cause of premature death of the plants, decreasing the service life of the orchards and increasing the cost of production. Aguiar et al. (2010) reported that fusariosis is the primary cause of premature death, resulting in severe economic losses by reducing the time of exploitation of the crop and limiting plant growth in some areas because the resistance structures of the fungus decrease yield and make production unfeasible. 
The use of wild species as resistant rootstocks has become an alternative increasingly considered for disease control and several studies highlight the need to use rootstocks for controlling the diseases caused by soil-borne pathogens (Aguiar et al., 2010; Nogueira Filho et al., 2011; Morgado et al., 2015). However, the use of wild species as seed rootstocks has been hampered, to a certain extent, by the difference in diameter between the rootstock and the graft, in addition to other morphological and phenological characteristics, and thus more detailed studies on interspecies viability and compatibility are necessary (Santos et al., 2014).

The objective of this study is to evaluate seed germination and the efficiency of grafting the yellow passion fruit ( $P$. edulis Sims.) on six Passifloraceae species.

The experiment was carried out in a greenhouse (seedling nursery with 50\% interception of light and transparent plastic cover) at the Department of Plant Sciences of the Federal Rural University of the Semi-Arid Region (Universidade Federal Rural do SemiÁrido-UFERSA) from January to May 2013.

The Passifloraceae species used as rootstocks were Passiflora foetida L., P. cincinnata Mast., P. ligularis Juss. (Granadilla), P. caerulea L., P. gibertii N. E. Brown, and P. edulis Sims. The seeds of $P$. foetida were collected in the Mossoró region. The seeds of $P$. edulis Sims. were of cultivar Redondo Amarelo (Topseed ${ }^{\circledR}$ ), and the other seeds were obtained from the seed bank of Embrapa Cerrados.

Sowing was performed in polyethylene bags $(0.7 \mathrm{~L})$ containing a substrate composed of soil (yellow-red latosol) and weathered bovine manure at the ratio of 3:1 combined with $500 \mathrm{~g}$ $\mathrm{m}^{3}$ of a commercial NPK formulation (4-14-8). Six treatments with four replicates of eight plants per plot were arranged in a completely randomized block design. After plant emergence was stabilized, the percentage of germination was determined by counting the number of emerged plants every two days. All evaluated species germinated between days 14 and 18 after seeding. After that, the plants were thinned to one plant per container.

After 30 days of sowing when the plants started emitting tendrils and the diameter of the grafts and rootstocks were compatible (5-6 mm), stems of $P$. edulis with two buds and no leaves were used for grafting by double-stem grafting. The rootstocks were cut with a pruning shear below the first pair of leaves at an average height of $10 \mathrm{~cm}$ from the base of the plant. A scalpel was used for grafting, and a biodegradable tape was used to protect and fix the grafted region. The grafted plants were transferred to a moist chamber in transparent plastic bags (4 $x 22 \mathrm{~cm}$ ) without fastening at the plant base to reduce dehydration and not interfere with gas exchange.

At 15 days after grafting, when the scions sprouted, the plastic bags were removed, and the rate of plant development was evaluated for all treatments. Survival was evaluated by observing the plants that remained alive every 15 days for up to 60 days after grafting, when the plants started emitting tendrils and the heights were uniform (60 to $70 \mathrm{~cm}$ ), which are ideal conditions for plant transplantation.

Percentage data were transformed into Arc.Sen $\sqrt{X}(\%) / 100$ for statistical analysis. The results were subjected to analysis of variance, and the estimated means were grouped by the Scott-Knott test $(p<0.05)$ using the statistical software Sisvar (Ferreira, 2011).

The mean percentage of germination was higher than 68\%, which is considered satisfactory considering that the uniformity and rates of germination of some wild passion fruit species are low. The Scott-Knott test (p $\leq 0.05$ ) allowed identifying distinct rates of germination. The highest mean rate $(98.20 \%)$ was found in $P$. edulis Sims. Whereas the lowest mean rate was found in $P$. caerulea and $P$. cincinnata $(43.00 \%)$ (Table 1).

Lima et al. (2006) observed that passion fruits grafted on $P$. edulis Sims. presented the highest mean percentage of germination compared to other species. Nogueira Filho et al. (2011) found that the rate of germination was comparatively low for passion fruit plants grafted on $P$. gibertii (32\%), $P$. cincinnata (33\%), and $P$. caerulea (55\%), corroborating to some extent the results of the present study. Germination can be affected by several factors, including seed age, 
phytosanitary conditions, and environmental conditions.

The seeds of $P$. foetida undergo dormancy, and the seed aril contains growthregulating substances, whichreduce germination. In this respect, Marostega et al. (2013) studied dormancy breaking in $P$. foetida and observed that the rate of germination of untreated seeds was lower than $30 \%$, which is lower than the rate found in this study (63\%), wherein dormancy breaking was not performed.

The results demonstrate the success of the technique in producing passion fruit seedlings, with development and survival rates higher than 70 and $85 \%$, respectively (Table 2 ).

Table 1. Percentage of germination of six species of passion fruit.

\begin{tabular}{|c|c|}
\hline Species & Germination (\%) $^{1}$ \\
\hline Passiflora foetida L. & $63,00 \mathrm{~d}$ \\
\hline Passiflora cincinnata Mast. & $43,00 \mathrm{e}$ \\
\hline Passiflora ligularis Juss. (Granadilla) & $92,00 \mathrm{~b}$ \\
\hline Passiflora edulis Sims. & $98,20 a$ \\
\hline Passiflora gibertii N. E. Brown & $71,00 \mathrm{c}$ \\
\hline Passiflora caerulea L. & 43,00 e \\
\hline Mean $^{2}$ & $68,37^{* *}$ \\
\hline C.V (\%) & 2,65 \\
\hline
\end{tabular}

Table 2. Porcentagens de pegamento (PEG) e de sobrevivência de enxertos utilizando o método de enxertia convencional do maracujazeiro amarelo sobre seis portaenxertos.

\begin{tabular}{|c|c|c|c|c|}
\hline \multirow{2}{*}{ Enxerto/portaenxerto } & \multirow{2}{*}{$\begin{array}{c}\text { PEG (\%) }{ }^{1} \\
15 \mathrm{DAE}\end{array}$} & \multicolumn{3}{|c|}{ Sobrevivência (\%)' } \\
\hline & & $30 \mathrm{DAE}$ & $45 \mathrm{DAE}$ & $60 \mathrm{DAE}$ \\
\hline P. edulis / P. foetida & $100,00 a$ & 100,00 & $100,00 a$ & $100,00 \mathrm{a}$ \\
\hline P. edulis / P. cincinnata & $100,00 \mathrm{a}$ & 100,00 & $85,71 \mathrm{~b}$ & $85,71 \mathrm{~b}$ \\
\hline P. edulis / P. ligularis & $90,00 \mathrm{~b}$ & 100,00 & $100,00 a$ & $100,00 \mathrm{a}$ \\
\hline P. edulis / P. edulis & $100,00 a$ & 100,00 & $100,00 a$ & $100,00 a$ \\
\hline P. edulis / P. gibertii & $70,00 \mathrm{c}$ & 100,00 & $100,00 \mathrm{a}$ & $100,00 \mathrm{a}$ \\
\hline P. edulis / P. caerulea & $100,00 \mathrm{a}$ & 100,00 & $100,00 \mathrm{a}$ & $100,00 \mathrm{a}$ \\
\hline Média $^{2}$ & $93,33^{* *}$ & $100,00^{\text {ns }}$ & $97,62^{* *}$ & $97,62^{* *}$ \\
\hline C.V (\%) & 0,21 & - & 0,16 & 0,16 \\
\hline
\end{tabular}

Several studies found promising results when grafting yellow passion fruit on wild species. Silva et al. (2011) reported that the rate of development was higher than $83.90 \%$ in plants grafted on four rootstocks ( $P$. alata, $P$. gibertii, P. suberosa, and P. edulis). Lenza et al. (95\%) observed that the rate of development was high in plants grafted on P. gibertii (93\%), 'FB200' (92\%), P. nitida (90\%), and P. alata (95\%). Similarly, Nogueira Filho et al. (2011) found that the rate of development of fruits grafted on $P$. caerulea, $P$. gibertii, $P$. cincinnata, and $P$. edulis f. flavicarpa was high. Morgado et al. (2015) found that the rates of development of plants grafted on $P$. alata, $P$. cincinnata, $P$. gibertii, and $P$. mucronata were higher than $90 \%$, whereas Santos et al. (2016) reported that the rates of development and survival of sour passion fruit plants grafted on $P$. edulis, P. gibertii, P. alata, and P. cincinnata were higher than $88 \%$.

The results using these rootstock species demonstrate the success of the technique, with high rates of development and survival at 60 days after grafting.

The results for $P$. foetida are promising but are not sufficient because the resistance of this species to premature death has not been determined. In this respect, grafted plants need to be exposed to several isolates and isolate mixtures or even to plants from regions with a history of premature death to assess the level and stability of resistance of this material.

\section{References}

ABF. Anuário brasileiro da fruticultura. 2016. http://www.grupogaz.com.br/tratadas/ 
eo_edicao/4/2016/04/20160414_0d40a2e2a/ pdf/5149_2016fruticultura.pdf < Acesso em 27 de jun. 2016>.

Aguiar, A. V. M., Silva, R. M., Cardoso, E. A., Maracajá, P. B., Pires, H. G. 2010. Utilização de espécies de Passiflora spp. como porta-enxertos no controle de doenças do maracujazeiro. Agropecuária Científica no Semi-Árido 6(4): p. 17-22.

Ferreira, D. F. 2011 . Sisvar: a computer statistical analysis system. Ciência e Agrotecnologia 35(6): p.1.039-1.042.

Lenza, J. B., Valente, J. P., Roncatto, G., Chig, L. A. 2009. Índice de pegamento e precocidade de mudas da variedade FB200 enxertada em diferentes espécies silvestres e comerciais de maracujazeiro. Revista Brasileira de Fruticultura 31 (3): p.831-836.

Lima, A. A., Caldas, R. C., Santos, V. R. 2006. Germinação e crescimento de espécies de maracujá. Revista Brasileira de Fruticultura 28(1): p.125-127.

Marostega, T. N., Ferraz, A. C. L., Araújo, L. M., Luz, P. B., Sobrinho, S. P., Neves, L. G. 2013. Superação de dormência em sementes de Passiflora foetida L.. Perspectiva 139(37): p.57-64.

Morgado, M. A. D., Bruckner, C. H., Rosado, L. D., Santos, C. E. M. dos S. 2015. Desenvolvimento de mudas de maracujazeiro-azedo enxertadas em espécies silvestres de Passiflora. Revista Brasileira de Fruticultura 37(2): p.471-479.

Nogueira Filho, G. C., Roncatto, G., Ruggiero, C., Oliveira, J. C., Malheiros, E. B. 2011. Produção de mudas de maracujazeiro-amarelo por enxertia hipocotiledonar sobre sete espécies de passifloras. Revista Brasileira de Fruticultura 33(1): p.237-245.

Santos, C. H. B., Cruz Neto, A. J. da., Soares, T. L., Oliveira, E. J. de., Jesus, O. N. de., Girardill, E. A. 2016. Porta-enxertos e fixadores de enxerto para enxertia hipocotiledonar de maracujazeiro azedo. Ciência Rural 46(1): p.30-35.

Santos, V. A., Ramos, J. D., Chagas, E. A., Dias, M. M., Locatelli, G., Oliveira, M. C. 2014. Enxertia de diferentes combinações de copas e portaenxertos em maracujazeiros. Semina: Ciências Agrárias 35(3): p.1201-1208.

Silva, R. M. da, Aguiar, A. V. M. de, Cardoso, E. de A., Souza, J. de O., Oliveira, L. A. de A. 2011 . Enxertia interespecífica do maracujazeiroamarelo sobre quatro portaenxertos. Revista Verde de Agroecologia e Desenvolvimento Sustentável 6(2): p.119-124. 